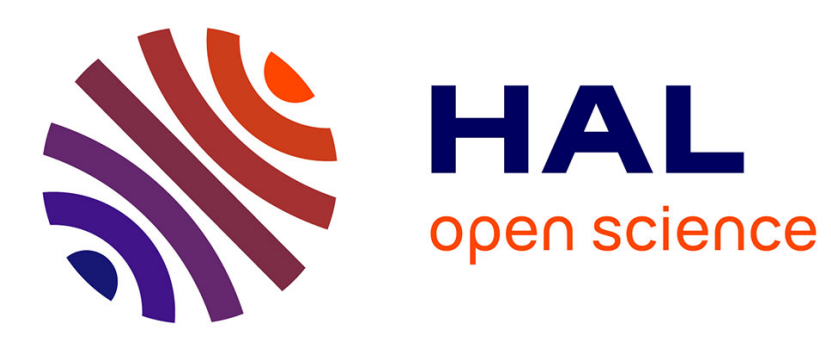

\title{
Experimental highlight of hygrothermal phenomena in hemp concrete wall
}

\author{
Florence Collet, Sylvie Pretot
}

\section{To cite this version:}

Florence Collet, Sylvie Pretot. Experimental highlight of hygrothermal phenomena in hemp concrete wall. Building and Environment, 2014, 82, pp.459-466. 10.1016/j.buildenv.2014.09.018 . hal01230379

HAL Id: hal-01230379

\section{https://hal-univ-rennes1.archives-ouvertes.fr/hal-01230379}

Submitted on 18 Nov 2015

HAL is a multi-disciplinary open access archive for the deposit and dissemination of scientific research documents, whether they are published or not. The documents may come from teaching and research institutions in France or abroad, or from public or private research centers.
L'archive ouverte pluridisciplinaire HAL, est destinée au dépôt et à la diffusion de documents scientifiques de niveau recherche, publiés ou non, émanant des établissements d'enseignement et de recherche français ou étrangers, des laboratoires publics ou privés. 


\title{
EXPERIMENTAL HIGHLIGHT OF HYGROTHERMAL PHENOMENA IN HEMP CONCRETE WALL Florence COLLET*, Sylvie PRETOT
}

Université Européenne de Bretagne - Laboratoire de Génie Civil et Génie Mécanique - Equipe Matériaux Thermo Rhéologie

Postal address: IUT Génie Civil - 3, rue du Clos Courtel - BP 90422 - 35704 Rennes - France

sylvie.pretot@univ-rennes1.fr

florence.collet@univ-rennes1.fr

* Corresponding author: Tel: 33.2.23.23.40.56, Fax: 33.2.23.23.40.51.

\begin{abstract}
This study investigates the hygrothermal behaviour of a timber-framed hemp concrete wall made of precast blocks. Measurements are performed on an uncoated wall as well as on a coated wall. The experimental device consists in two air-conditioned rooms where ambient conditions are selected to induce temperature and/or vapour pressure gradient between the two sides of the wall. The monitoring deals with temperature and relative humidity within the wall. Kinetics of temperature and of vapour pressure are given. Profiles are drawn at several times of the transient phase. In the regular part of the wall, several kinds of hygric behaviours are highlighted such as homogeneous vapour diffusion and huge vapour pressure variations due to evaporation-condensation and/or sorption-desorption phenomena. The results in the line of frame show that the frame doesn't induce disturbances in the hygrothermal behaviour of the wall. It is also shown that the coating reduces and delays vapour diffusion.
\end{abstract}

Keywords: bio-based material, hygrothermal behaviour, sorption-desorption, evaporation-condensation.

\section{Introduction}


Nowadays, responsible construction should be energy efficient and made of environmentally friendly materials. Bio-based materials avoid depletion of raw material and exhibit low impact on environment (carbon storage, low embedded energy...) [1]. Hemp concrete is a bio-based building material made of lime and hemp shiv. This material can be used for several applications (wall, floor and roof) adjusting the composition. It is implemented by casting, spraying or pre-casting. Due to its low mechanical performances, hemp concrete is used with a framework that can be made of steel, concrete or wood. Usually, hemp concrete walls are coated on both sides but hemp concrete can occasionally be naked on the indoor side.

The experimental characterization of hygrothermal behaviour of hemp concrete is widely investigated at material scale. Measurements provide thermal and hydric properties that are available in the literature.

Hemp concrete is a lightweight building material. Its thermal conductivity depends both on its formulation, its density and its water content. It ranges from 0.07 to $0.3 \mathrm{~W} \cdot \mathrm{m}^{-1} \cdot \mathrm{K}^{-1}$. Hemp concrete is therefore a good, not exceptional, thermal insulator [2] [3] [4] [5] [6] [7] [8]. Like all bio-aggregate based building materials, hemp concrete is strongly hygroscopic. Its water uptake is much higher than in usual building materials, as shown in [9] by comparing hemp concrete with Aerated Autoclaved Concrete and with Vertical Perforated Bricks. The water content at equilibrium at very high relative humidity (95 $\% \mathrm{RH})$ is much lower than the water content at saturation [10]. This is linked to the macroporosity due to the bio-based aggregate. Moreover, its sorption curves show hysteresis which extends all over the range of relative humidity [11] [12] [13] [14]. The mainly open high porosity of bio-aggregate based building materials gives them high moisture vapour permeability (ie low water vapour diffusion resistance). The water vapour diffusion resistance, at dry point, ranges from 5 to 12 for hemp concrete [7] [11] [15] while it is equal to 130 for solid concrete, 50 for light weight aggregate (natural pumice stone) concrete, and 10 for aerated autoclaved concrete [16]. Finally, the moisture buffering quality of hemp concrete was studied by several authors [14] [17] [18] [19] [20] [21] [22]. The experimental investigations are generally performed following the Nordtest protocol [23]. It is shown that hemp concrete is an excellent hygric regulator with moisture buffer values globally higher than $2 \mathrm{~g} /\left(\mathrm{m}^{2} . \% \mathrm{RH}\right)$. 
The hygic and thermal properties of bio-aggregate based building materials give them a particular hygrothermal behaviour which allows reducing the energy demand of buildings while maintaining indoor relative humidity [24] [25]. The investigations of the hygrothermal behaviour of building materials at large scale, found in literature, are generally performed numerically. Experimental studies are also performed at large scale $\left(1 \mathrm{~m}^{2}\right.$, wall or building).

It was shown in [25] and in [26] that hemp concrete wall performs better than traditional wall assembling on a phase shift point of view. For example, in the simulation of [25] the phase shift was $15 \mathrm{~h}$ in the hemp concrete wall while it was $5 \mathrm{~h}$ in the mineral wool wall. These performances are correlated with hygric behaviour of hemp concrete. Actually, Shea et al. [26] underline that, after a sudden drop in temperature on one side of the experimental wall, the steady state is reached at approximately $240 \mathrm{~h}$ while it is reached within $72 \mathrm{~h}$ in simulations ignoring the effects of relative humidity. Thus, relative humidity has a strong effect on the hygrothermal behaviour of the wall. The experimental study reported by Arnaud, Samri and Gourlay in [9] shows that an internal source (or well) of heat and/or the presence of another flow of heat (notably by convection) exists in hemp concrete and directly impact the heat balance equation.

Mlakar and Strancar compared hygrothermal behaviour of small-scale test houses with several kinds of materials [27]. Among their results, the lack of moisture buffering materials leads to higher level and larger oscillation of indoor relative humidity. The authors underline that high moisture loads could have an impact on the durability of buildings and also on its energy performance. At building scale, Woloszyn et al. [28] studied the effect of combining relative-humidity-sensitive ventilation with moisture buffering materials on relative humidity and energy consumption. They show that the use of moisture buffering materials allows reducing the amplitude of daily moisture variation and that energy savings are realised, thanks to SRH ventilation. Tran Le et al. compare hemp concrete behaviour to that of cellular concrete [24]. They found that hemp concrete induces a reduction ranging from $15 \%$ to $45 \%$ in energy consumption, depending on ventilation strategy. More, Maalouf et al. compare hemp concrete with other building materials (cellular concrete, earth block, solid brick, concrete)[29]. They show that hemp concrete has the lowest thermal diffusivity and the highest time lag which means that it can better reduce the propagation of outdoor weather conditions through building envelope. However, these authors also 
show that, in South France, there is a risk of indoor superheating due to low effusivity of hemp concrete. Besides, they underline that hygric properties are high affecting parameters.

The aim of this study is to learn more about the practical behaviour of hemp concrete wall. This study is performed at wall scale in order to respect the usual implementation. The studied hemp concrete woodframed wall is made of precast blocks. The experimental device is made of two air-conditioned rooms. The monitoring deals with temperature and relative humidity within the wall in the regular part of blocks and in the front of wood framework. The experimental device and the implementation of the wall are first presented. Then the results obtained under several ambient conditions in the rooms are given. These conditions are selected to have vapour transfer, heat transfer or simultaneous heat and vapour transfer. Kinetics of temperature and vapour pressure are given and profiles are drawn at several times of the transient phase.

\section{Experimental method}

\subsection{Experimental device}

This study focuses on the hygrothermal behaviour of a hemp concrete wall under hygrothermal stresses. The aim is to study the wall response under temperature gradient only, vapour pressure gradient only and finally under both temperature and vapour pressure gradients. So, in order to well control ambient temperature and relative humidity on both sides of the wall, the experimental device involves two adjacent air-conditioned rooms separated by the studied test-wall.

Each room is $2.35 \mathrm{~m}$ deep, $2.78 \mathrm{~m}$ wide and $2.4 \mathrm{~m}$ high. The floor is made of concrete and all the other walls of the rooms are well insulated by polyurethane panels $\left(\mathrm{U}=0.40 \mathrm{~W} \cdot \mathrm{m}^{-2} \cdot \mathrm{K}^{-1}\right)$ and are air and moisture tight. One of the air-conditioned rooms reproduces the indoor climate of common buildings ("indoor room") while the other one simulates outdoor climatic conditions ("outdoor room"). Table 1 gives the ranges of temperature and relative humidity for each room. The regulation of each parameter ( $\mathrm{T}$ and RH) is ensured by universal controllers DR4020 used to define the set point and a bandwidth that governs the switch-on and the switch-off of the devices of the chambers. Each controller has two outputs: heating / cooling for the temperature regulation and humidification / dehumidification for the humidity 
regulation. Heating is provided by convectors, cooling and dehumidification by a refrigeration group and humidification by steam humidifiers. When systems are operating, fans with low rotational speed are employed. This induces low level of air movement, with mean vertical velocity lower than $0.1 \mathrm{~m} . \mathrm{s}-1$ in the studied part of the wall. This is not higher than the value commonly met in buildings. Hence, the rate of evaporation and moisture movement are not enhanced by the fan use.

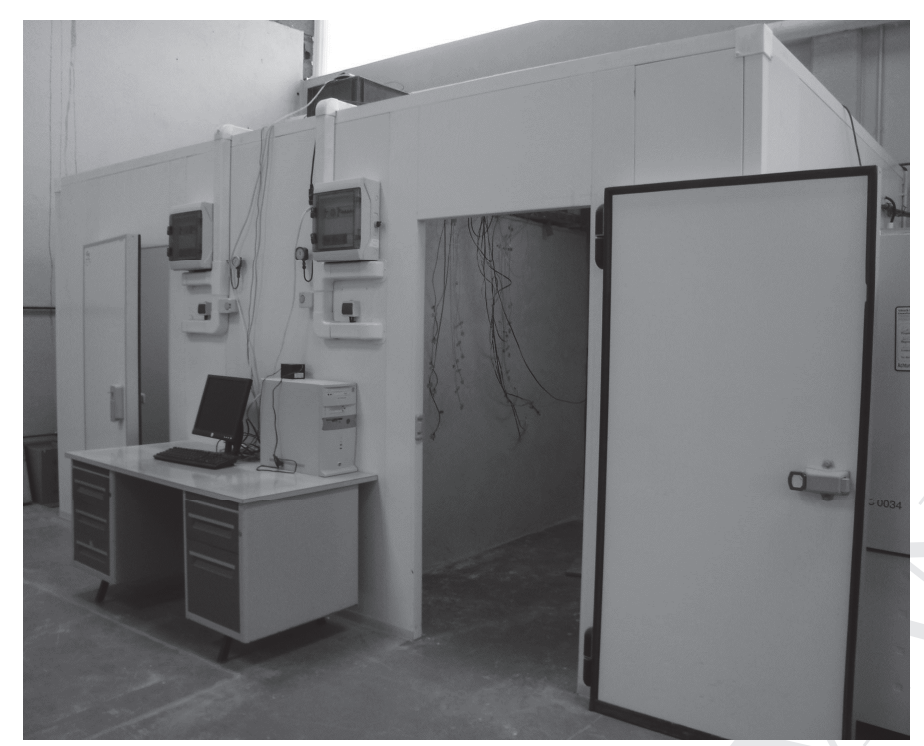

Figure 1. Experimental device: bi-climatic rooms

Table 1: Ranges of temperature and relative humidity

\begin{tabular}{lcccc}
\hline & Room 1 (indoor) & Room 2 (outdoor) \\
\hline & Range & Bandwidth & Range & Bandwidth \\
\hline Temperature $\left({ }^{\circ} \mathrm{C}\right)$ & $18-27$ & \pm 0.2 & $-5-35$ & \pm 0.5 \\
\hline Relative humidity $(\% \mathrm{RH})$ & $30-60$ & \pm 0.3 & $30-90$ & \pm 0.8 \\
\hline
\end{tabular}

\subsection{Test wall and metrology}

The test wall is built with precast hemp concrete blocks (see the dimensions of blocks in figure 6) and a wooden frame. The precasting consists in mixing binder and hemp shiv and then forming blocks. The binder is made of $72 \%$ in mass of $\mathrm{CaO}$ and $28 \%$ of hydraulic binder (lime and pozzolan). The hemp to binder mass ratio is $65 \%$ and the water to binder ratio is $120 \%$. Firstly, $\mathrm{CaO}$ is mixed with water to obtain slaked lime. Then hydraulic lime and hemp shiv are added. The mixture is then poured into moulds and blocks are formed by compaction in the moulds under vibrations (figure 2). These blocks show holes to 
introduce the wood frame $\left(17 \times 8 \mathrm{~cm}^{2}\right)$ and holes for networks $(\varnothing 5 \mathrm{~cm})$ (figure 3$)$. The apparent density of these blocks is $320 \mathrm{~kg} \cdot \mathrm{m}^{-3}$, their thermal conductivity (at $23^{\circ} \mathrm{C}, 50 \% \mathrm{RH}$ ) is $0.12 \mathrm{~W} \cdot \mathrm{m}^{-1} \cdot \mathrm{K}^{-1}$ and their water vapour permeability is $1 \mathrm{E}^{-10} \mathrm{~kg} \cdot \mathrm{m}^{-1} \cdot \mathrm{s}^{-1} \cdot \mathrm{Pa}^{-1}$ [30]. The wood frame is made of semi-heavy pine wood. According to [16], this kind of wood shows dry density from 435 to $520 \mathrm{~kg} \cdot \mathrm{m}^{-3}$, thermal conductivity about $0.15 \mathrm{~W} \cdot \mathrm{m}^{-1} \cdot \mathrm{K}^{-1}$ and water vapour permeability about $0.4 \mathrm{E}^{-10} \mathrm{~kg} \cdot \mathrm{m}^{-1} \cdot \mathrm{s}^{-1} \cdot \mathrm{Pa}^{-1}$.
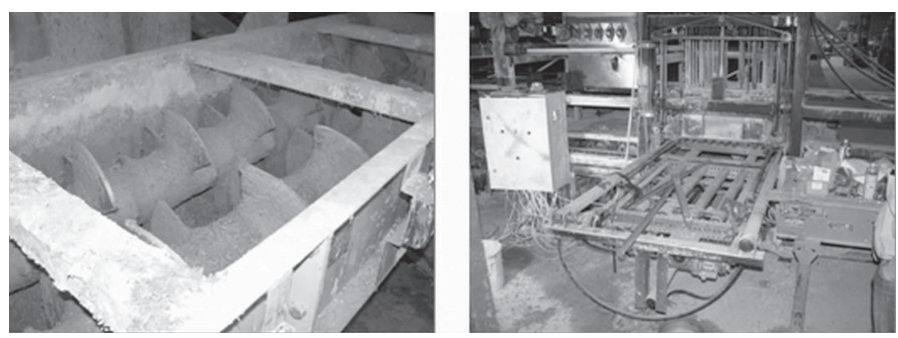

Figure 2. Device for precasting hemp concrete - mixer; forming process.

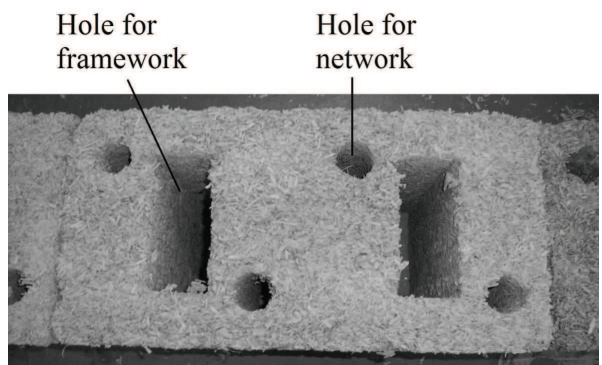

Figure 3. Hemp concrete block

The test wall is $2.30 \mathrm{~m}$ long, $0.30 \mathrm{~m}$ thick and $2.1 \mathrm{~m}$ high (figure 4). The horizontal joints between the rows of pre-cast blocks are narrow joints made of a few millimetres of milk of lime (25 $\mathrm{kg}$ of natural hydraulic lime with 101 of water). The vertical joints between blocks are filled with a mixture made of hemp shiv and lime, as best as possible. The cross section of the frame is $15 \times 5 \mathrm{~cm}^{2}$. The space between the wood and the hemp concrete is filled with a milk of lime. This wall is highly heterogeneous (regular part of the block, joints, timber frame, reservation holes...). 


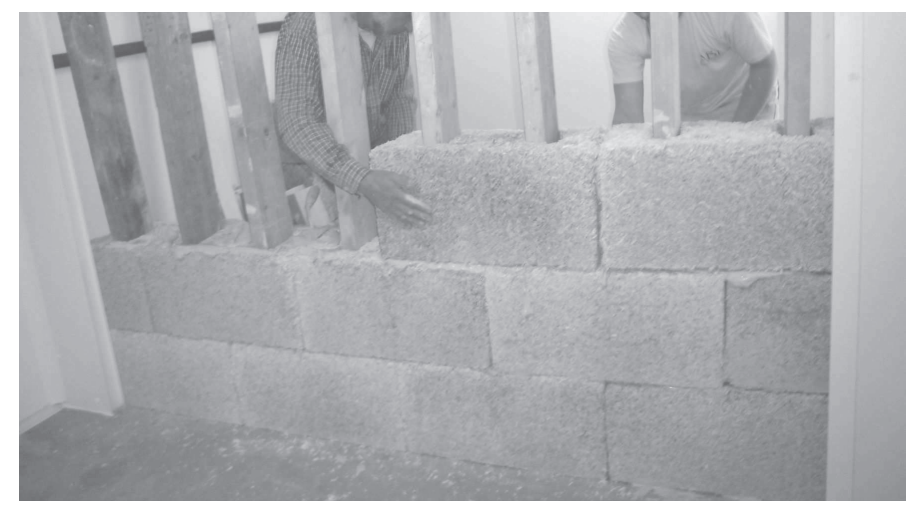

Figure 4. Building of the test wall

The aim of the monitoring is to measure the hygrothermal response of the wall to environmental conditions (temperature and relative humidity). Temperature is measured with thermocouples (type K) on the one hand, and with sensirion SHT75 sensors on the other hand. These sensors also measure relative humidity. The accuracy of thermocouples is $\pm 0.1^{\circ} \mathrm{C}$. They were checked at $0^{\circ} \mathrm{C}, 10^{\circ} \mathrm{C}, 20^{\circ} \mathrm{C}$ and $30^{\circ} \mathrm{C}$. The accuracies of sensors SHT 75 are $\pm 0.3^{\circ} \mathrm{C}$ at $25^{\circ} \mathrm{C}$ and $\pm 1.8 \% \mathrm{RH}$ at $10-90 \% \mathrm{RH}$. In order to quantify the absolute quantity of moisture, vapour pressure is calculated from temperature and relative humidity with the usual relationship:

$$
p_{v}=\varphi \cdot 100 \exp \left(18.986-\frac{4052}{235.89+T}\right)
$$

The measurements are carried out on ambient air, on the surface of the wall and within the wall. Due to the heterogeneity of the wall, several profiles are studied. Figure 5 shows the numbering of blocks (1 to 31 ) and columns (1 to 8$)$ and the location of sensors. Profiles are measured in the regular part of blocks 17 and 20 and in the line with the timber frame (columns 3 and 6). In order not to disturb each other, the sensors are installed with an angle of $45^{\circ}$ and distributed at different levels (figure 6). 

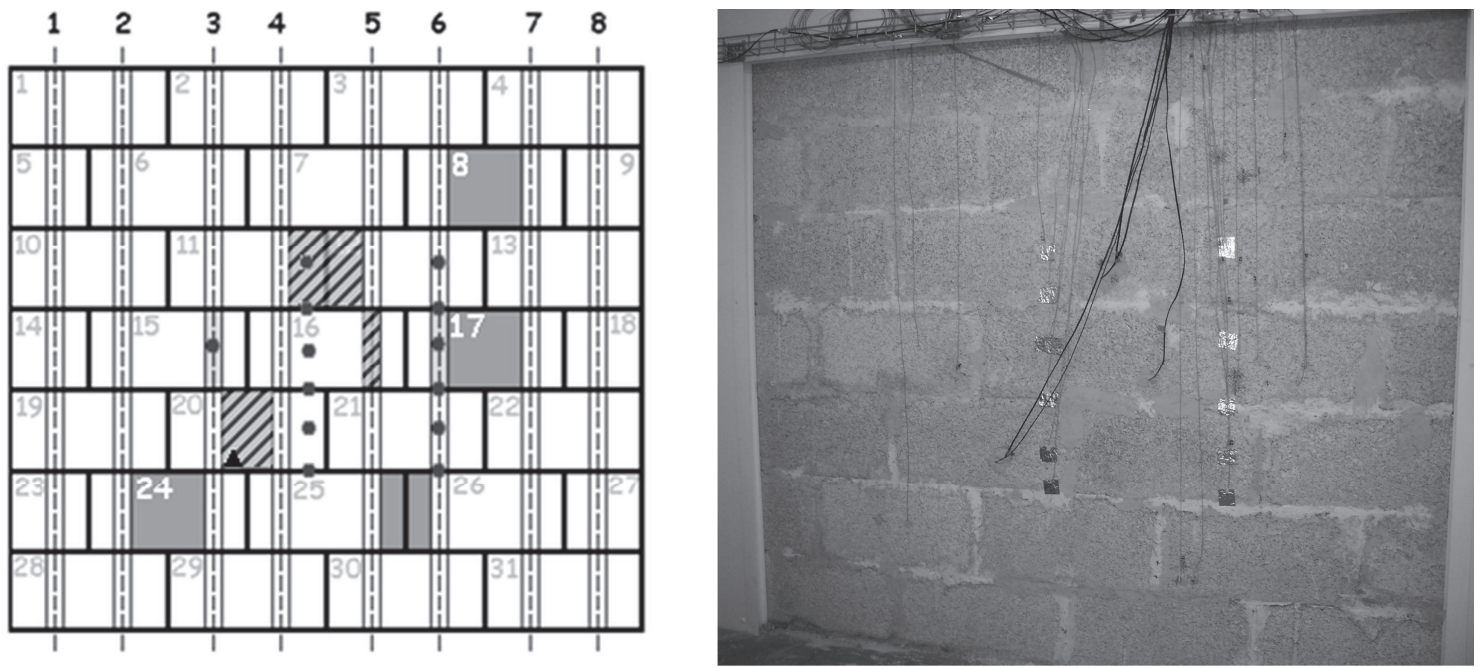

\section{Surface sensors Profils in blocks and joints of blocks}

- Thermocouple

A Sensirion SHT 75
Thermocouple

Sensirion SHT 75
Profils in the line of framework

III Thermocouple

a Sensirion SHT 75

Figure 5. Instrumentation of the test wall for the monitoring of temperature and relative humidity

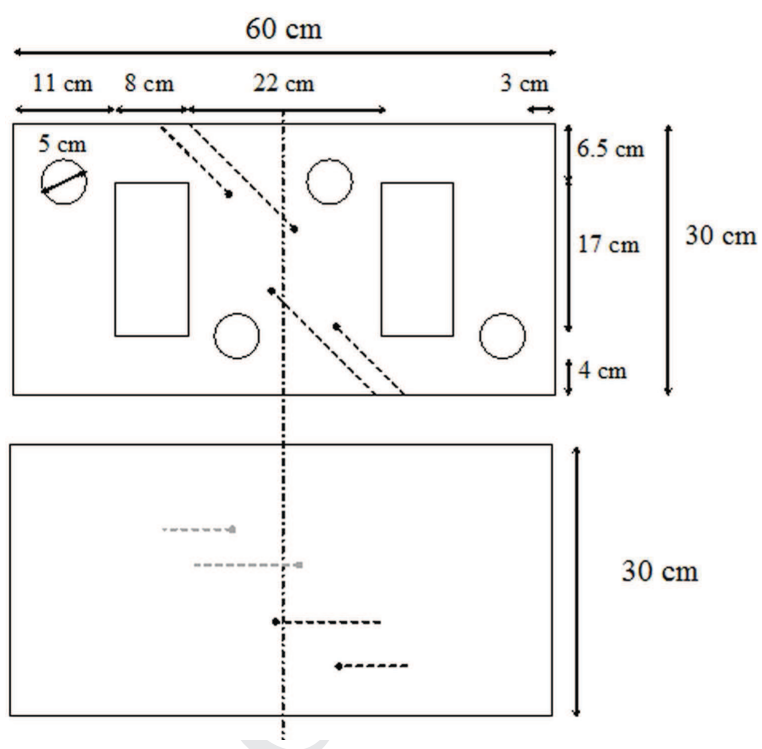

Figure 6. Sensors location in a block (up : top view, down : front view)

\subsection{Methodology}

Four months later the construction (drying of the wall), the whole device is stabilized with the same setpoint for indoor and outdoor climates: $23^{\circ} \mathrm{C}, 40 \% \mathrm{RH}$. Then, the set points of the ambient conditions are chosen in order to ensure uncoupled or coupled heat and mass transfer. Temperatures and relative 
humidities considered are in the range of the values met in temperate climate. They are chosen in order to ensure a high enough gradient to provide meaningful results.

Both during the stabilization phase and during the test phase, the time step between measurements is five minutes.

Firstly, measurements are performed on uncoated wall. Then both sides of the wall are coated with a breathable commercial lime based coating (water vapour diffusion factor lower than 35 ). This coating is made of hydrated lime, low quantity of hydraulic binders, silicate and calcareous sand and mineral pigment. It is applied in two five-millimetre thick layers. Then, sensors are added on the surface of the coated wall.

\section{Results and discussion}

The response time of air conditioning is firstly considered. Then, the hygrothermal response of the wall under hygrothermal stress is detailed for uncoated wall and then for coated wall. In both cases, the study is performed under temperature gradient only, vapour pressure gradient only and finally simultaneous temperature and vapour pressure gradients.

\subsection{Performance of air conditioning}

Several ambient conditions are considered. For all cases, the response time of air conditioning is short. For example, figure 7 shows the ambient temperature and relative humidity values of each room after stabilization at $23^{\circ} \mathrm{C} 40 \%$ on both sides of the wall when the ambient conditions of the outdoor room are set to $9^{\circ} \mathrm{C}, 75 \% \mathrm{RH}$. The setpoints are quickly reached as well for the temperature as for the relative humidity. This is mainly due to the low inertia of the bi-climatic rooms. The curves show small fluctuations around the setpoints due to the power of the air conditioning system and to its on/off regulation. 

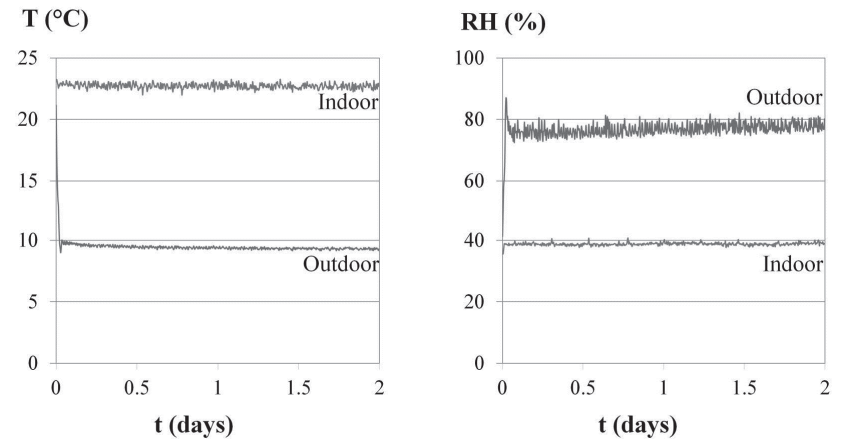

Figure 7: Kinetics of the ambient temperature and relative humidity for the following setpoints: indoor $23^{\circ} \mathrm{C} 40 \% \mathrm{RH}$ outdoor $9^{\circ} \mathrm{C} 75 \% \mathrm{RH}$.

\subsection{Hygrothermal behaviour of uncoated hemp concrete wall}

\subsubsection{Hygrothermal behaviour in the regular part of hemp concrete blocks}

In the first case studied, the setpoints are chosen to ensure only a vapour pressure gradient between the two rooms. After stabilization at $23^{\circ} \mathrm{C}, 40 \% \mathrm{RH}$, the outdoor temperature and relative humidity are set to $23^{\circ} \mathrm{C}, 80 \% \mathrm{RH}$ while the indoor ones are kept at $23^{\circ} \mathrm{C}, 40 \% \mathrm{RH}$. Such conditions lead to a vapour transfer from the outdoor to the indoor side. Figure 8 gives the kinetic of vapour pressure at several depths within the wall.

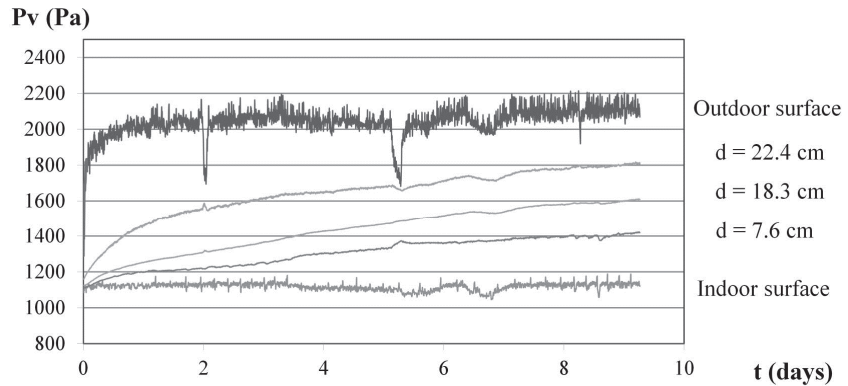

Figure 8: Kinetics of vapour pressure in a block after stabilization at $23^{\circ} \mathrm{C} 40 \% \mathrm{RH}$ when outdoor setpoint is set to $23^{\circ} \mathrm{C}$ $80 \% \mathrm{RH}$ and indoor is kept at $23^{\circ} \mathrm{C} 40 \% \mathrm{RH}$.

The steady state is reached after seven days all over the thickness of the wall. At initial time, the vapour pressure is almost the same in the whole thickness of the wall because the ambient values in the rooms are similar. After changing the setpoints, the vapour pressure increases through the wall. The closer to the solicitation (outdoor side), the greater and quicker the increase is. For example, the vapour pressure 
increases by $302 \mathrm{~Pa}$ at $7.6 \mathrm{~cm}$ depth from indoor side and by $643 \mathrm{~Pa}$ at $22.4 \mathrm{~cm}$ depth. After one day, these increases are respectively $20 \%$ and $30 \%$ of the final variation. Finally, the vapour pressure profile tends towards a linear profile (figure 9). It is characteristic of homogeneous moisture diffusion through the wall.
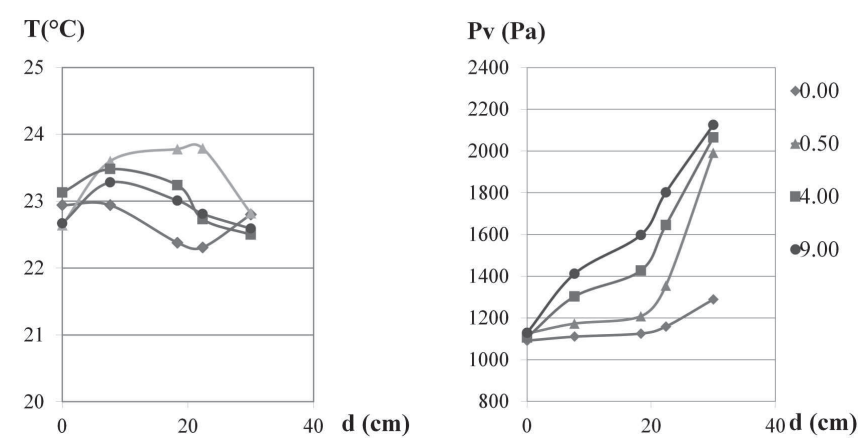

Figure 9: Temperature and vapour pressure profiles obtained at several times, when outdoor setpoint is changed from $23^{\circ} \mathrm{C}$ $40 \% \mathrm{RH}$ to $23^{\circ} \mathrm{C} 80 \% \mathrm{RH}$

In the second case, the wall is initially exposed to temperature and vapour pressure gradients (indoor at $23^{\circ} \mathrm{C}, 40 \% \mathrm{RH}$ and outdoor at $\left.15^{\circ} \mathrm{C} 45 \% \mathrm{RH}\right)$. Then the setpoints are changed such as the vapour pressures are nearly the same on both sides of the wall whereas a temperature gradient appears: the outdoor room is changed to $30^{\circ} \mathrm{C} 27 \% \mathrm{RH}$ while the indoor is kept at $23^{\circ} \mathrm{C} 40 \% \mathrm{RH}$. The outdoor setpoint is not exactly reached and the test is held under outdoor conditions of $28^{\circ} \mathrm{C} 32 \% \mathrm{RH}$. Figure 10 gives the kinetics of temperature and vapour pressure within block 20. Figure 11 gives the profiles of temperature and vapour pressure at several times. This figure shows the good agreement between the measures on the two blocks and underlines that this is representative of the hygrothermal behaviour in the regular part of the wall. The monitoring shows that the temperature evolves quickly: $90 \%$ of the final variation of temperature is reached after 2.5 days at a $22.6 \mathrm{~cm}$ depth from interior side (figure 10). The steady state is reached after 5 days. Obviously, initial and final time temperature profiles are linear with opposite slope (figure 11). This is correlated with the heat transfer flow. Initially, the temperature gradient in the wall induces a thermal flux from the indoor to the outdoor side. When the outdoor setpoint is changed, a thermal flux occurs from outdoor to indoor. These two fluxes are simultaneous until the temperature within the wall reaches the indoor one. Then only the thermal flux from outdoor to indoor occurs. Regarding vapour transfer, the vapour pressure inside the wall evolves quickly. Less than one 
hour after changing the setpoint, a pressure peak is observed through the material. The vapour pressure observed is higher than those measured in the rooms. This highlights sorption-desorption phenomena in the material. These phenomena induce heat of sorption-desorption exchange simultaneously with thermal transfer, this impacts the global energy balance of the wall. Finally, the vapour pressure tends towards a constant value that is nearly reached after 10 days (figure 11).

$\mathbf{T}\left({ }^{\circ} \mathbf{C}\right)$

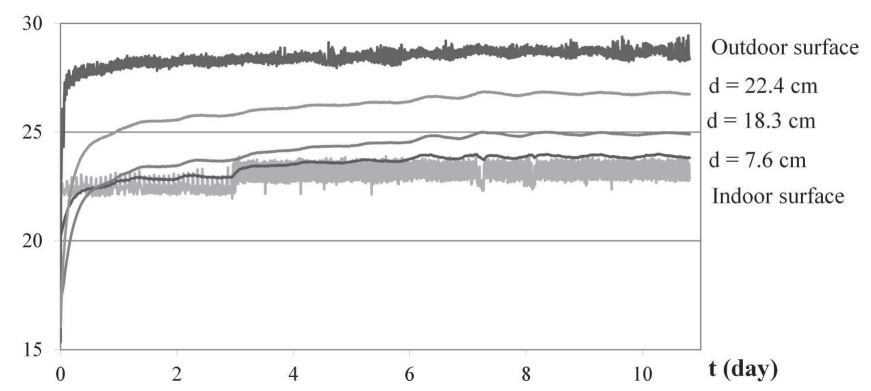

$\operatorname{Pv}(\mathbf{P a})$

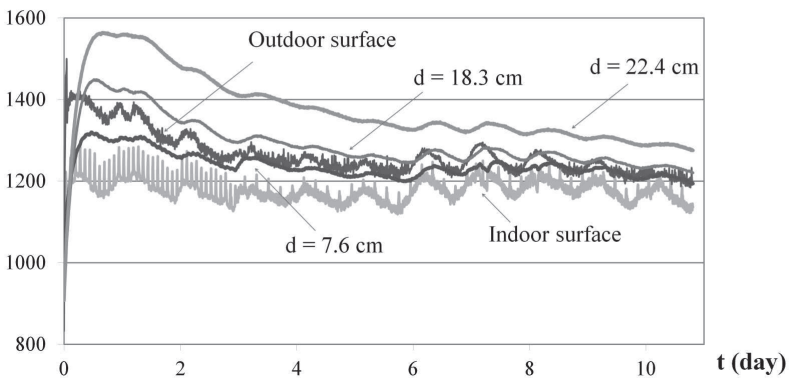

Figure 10: Temperature and vapour pressure kinetic when the outdoor setpoint is set from $15^{\circ} \mathrm{C} 45 \% \mathrm{RH}$ to $28^{\circ} \mathrm{C} 32 \% \mathrm{RH}$.
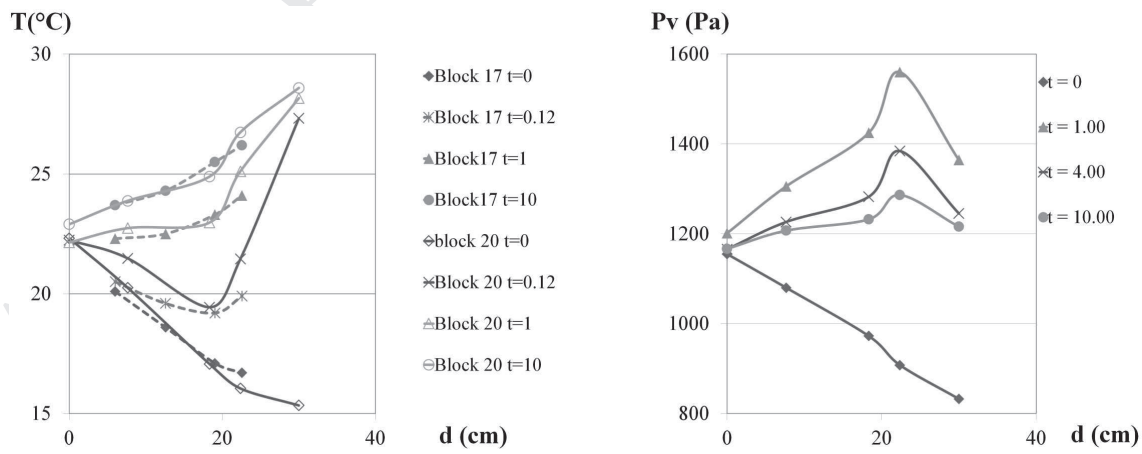

Figure 11: Temperature and vapour pressure profiles when the outdoor setpoint is set from $15^{\circ} \mathrm{C} 45 \% \mathrm{RH}$ to $28^{\circ} \mathrm{C} 32 \% \mathrm{RH}$.

The third case investigates simultaneous heat and mass transfers under temperature and vapour pressure gradients. Both fluxes occur from the indoor to the outdoor side of the wall. The studied system is first stabilized at $23^{\circ} \mathrm{C} 40 \% \mathrm{RH}$. After that, the setpoint of the outdoor side is changed to $9.5^{\circ} \mathrm{C} 77 \% \mathrm{RH}$ while 
the indoor side is kept at $23^{\circ} \mathrm{C} 40 \% \mathrm{RH}$. Temperature and vapour pressure kinetics are plotted on figure 12. The vapour pressure decreases quickly near the outdoor side of the wall before increasing slightly until stabilization. The same phenomenon occurs within the material with a phase shift, a damping and with greater time constants for the fall and rise in vapour pressure. The vapour pressure reaches lower values than the stabilized ones that shows sorption-desorption and/or evaporation- condensation phenomena.

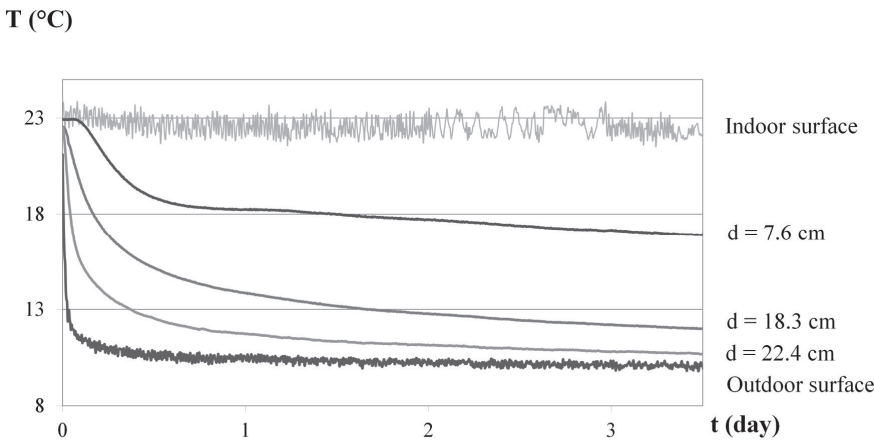

Pv (Pa)

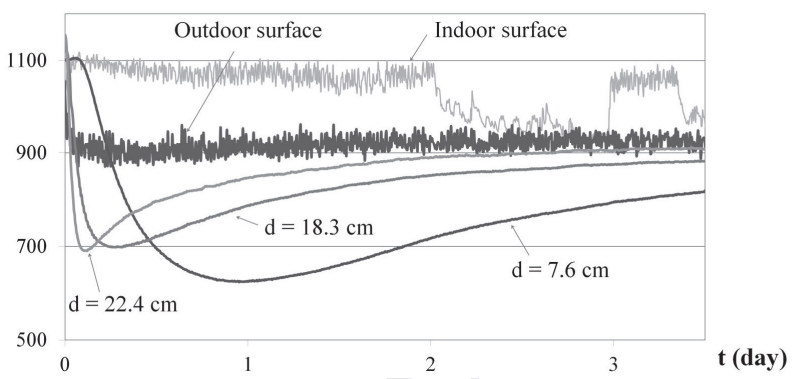

Figure 12. Temperature and vapour pressure kinetics when the outdoor setpoint is set from $23^{\circ} \mathrm{C} 40 \% \mathrm{RH}$ to $9.5^{\circ} \mathrm{C} 77 \% \mathrm{RH}$.

\subsubsection{Hygrothermal behaviour in line with the timber frame}

The hygrothermal behaviour in line with the timber frame is presented for an indoor setpoint equal to $23^{\circ} \mathrm{C} 40 \% \mathrm{RH}$ whereas the outdoor one is set from $15^{\circ} \mathrm{C} 45 \% \mathrm{RH}$ to $28^{\circ} \mathrm{C} 32 \% \mathrm{RH}$ (figures 13 and 14 ). The wall is thus initially exposed to temperature and vapour pressure gradients and finally to temperature gradient only. The kinetics measured in contact with the timber frame change in the same trend as those measured in the regular part of the blocks as well for the temperature as for the vapour pressure. Thus, the 
timber frame does not seem to induce high phase shift in the propagation of heat and moisture fluxes. Temperature profiles in front of the timber frame are similar to those measured in the regular part of the block all along the transient phase. So, the timber frame does not disturb significantly the heat transfer and storage in the wall. No thermal bridges occur because the hemp concrete and wood have similar thermal conductivities. Furthermore infrared thermographic imaging was performed with a Flir B50 camera. The difference of ambient temperature between the interior and the exterior side of the wall was about $10^{\circ} \mathrm{C}$ for several days before the imaging begins. This gradient ensures high enough thermal transfer to induce surface temperature differences in case of thermal bridge. The air velocity is low enough to not disturb the measurement. Infrared thermographic images show a uniform temperature field on the surface of the coated wall. The vapour pressure profiles in line with the timber frame are also similar to those measured in the regular part of the block. Thus, the influence of the timber frame on the moisture transfer and storage within the wall is limited.
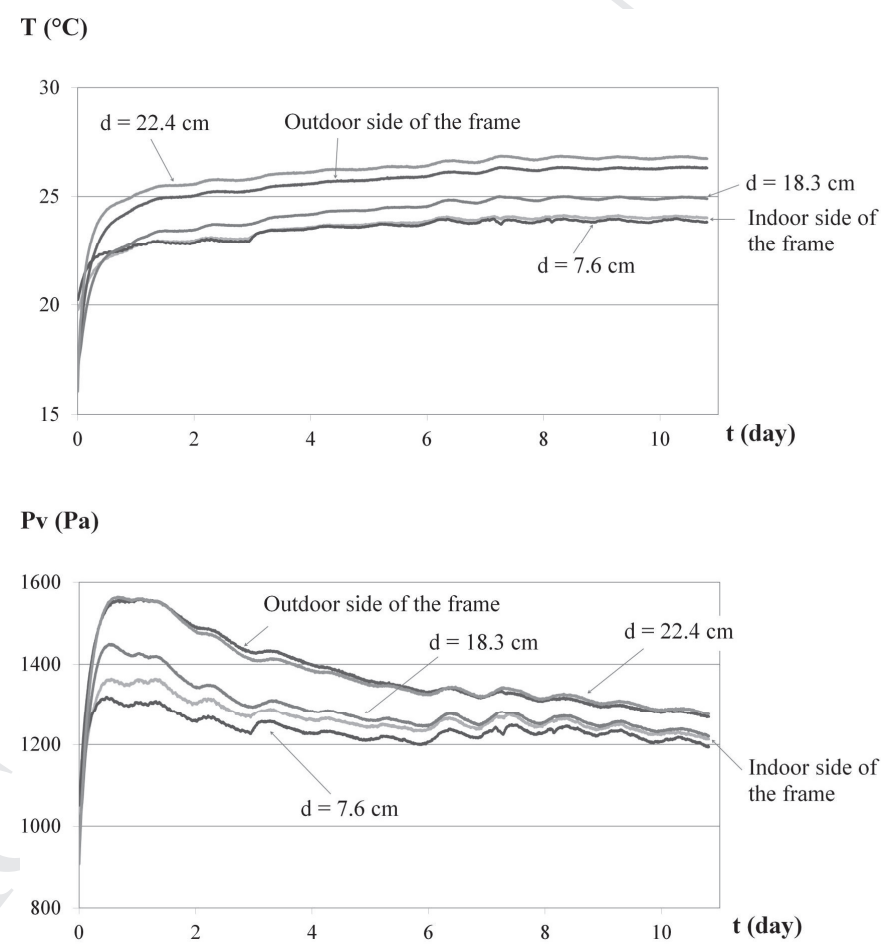

Figure 13. Temperature and vapour pressure kinetics when the indoor setpoint is kept at $23^{\circ} \mathrm{C} 40 \% \mathrm{RH}$ and the outdoor setpoint is set from $15^{\circ} \mathrm{C} 45 \% \mathrm{RH}$ to $28^{\circ} \mathrm{C} 32 \% \mathrm{RH}$. 

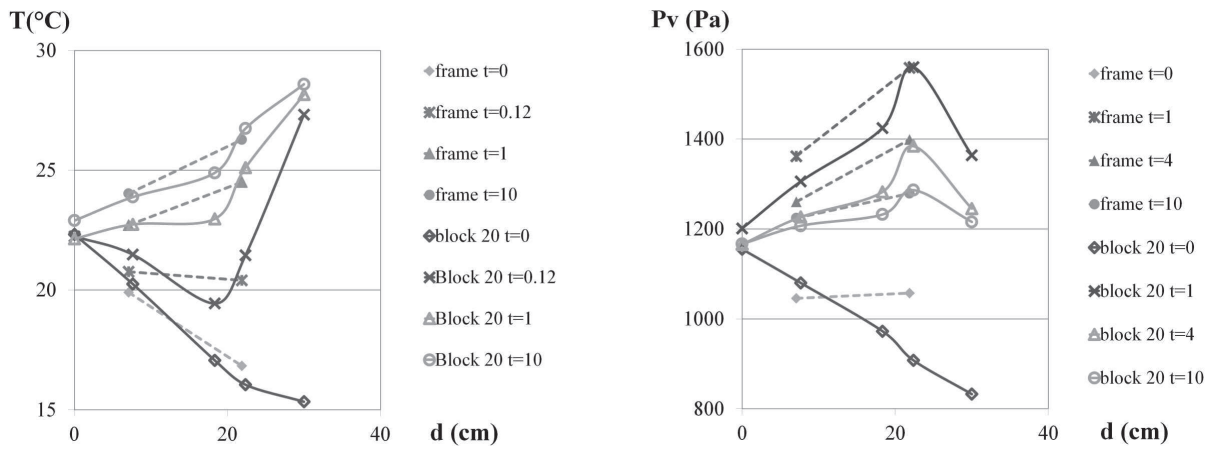

Figure 14. Temperature and vapour pressure profiles when the indoor setpoint is kept at $23^{\circ} \mathrm{C} 40 \% \mathrm{RH}$ and the outdoor setpoint is set from $15^{\circ} \mathrm{C} 45 \% \mathrm{RH}$ to $28^{\circ} \mathrm{C} 32 \% \mathrm{RH}$.

\subsection{Hygrothermal behaviour of coated hemp concrete wall}

Figure 15 shows the kinetics in the coated wall exposed to vapour flux. The outdoor setpoint is set from $23^{\circ} \mathrm{C} 40 \% \mathrm{RH}$ to $23^{\circ} \mathrm{C} 80 \% \mathrm{RH}$ while the indoor setpoint is kept at $23^{\circ} \mathrm{C} 40 \% \mathrm{RH}$. The outdoor relative humidity reached is slightly higher than the setpoint.

At initial state, the vapour pressure profile shows constant value through the wall as indoor and outdoor conditions are the same. Once outdoor setpoint is changed, vapour pressure shows higher gradient near the outdoor side of the wall. The vapour pressure within the coated wall tends to a linear profile.

However, after 6 days of exposure, this profile is less linear than the one observed without coating after 4 days of exposure. This is probably due to slower vapour diffusion through the wall.

In order to compare kinetics with and without coating, figure 16 shows the plot of the ratio $\left(\mathrm{P}_{\mathrm{v}^{-}}\right.$ $\left.\mathrm{Pv}_{\text {indoor }}\right) /\left(\mathrm{P}_{\text {voutdoor,average }}-\mathrm{Pv}_{\text {indoor,average }}\right)$. This shows that the slopes for the uncoated wall are lower than the slopes for the coated wall. Moreover, vapour pressures are lower within the coated wall than within the uncoated one. This is particularly obvious near the outdoor side of the wall. So, the coating induces an additive vapour resistance that reduces and delays the vapour transfer through the wall. Such effect was also observed in [31] measuring the moisture buffer value of naked and coated hemp concrete. So, coating highly impacts the vapour transfer through the wall. However, it does not stop the sorptiondesorption and/or evaporation-condensation phenomena in hemp concrete. 

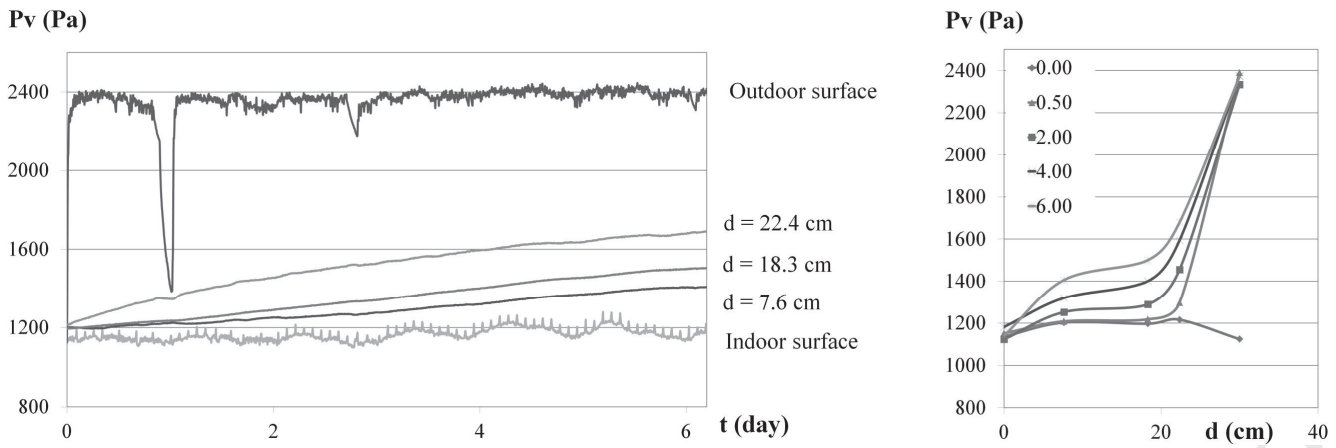

Figure 15. Vapour pressure kinetics and profiles of the coated wall when the outdoor setpoint is set from $23^{\circ} \mathrm{C} 40 \% \mathrm{RH}$ to $23^{\circ} \mathrm{C} \mathrm{80 \% RH}$

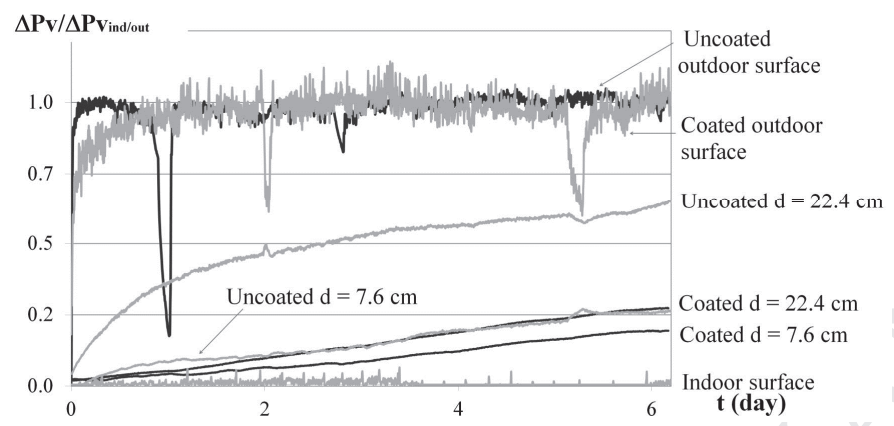

Figure 16. Comparison of kinetics of the coated and of the uncoated wall when the outdoor setpoint is set from $23^{\circ} \mathrm{C} 40 \% \mathrm{RH}$ to $23^{\circ} \mathrm{C} 80 \% \mathrm{RH}$

\section{Conclusion}

The experimental device is well adapted to study hygrothermal behaviour of a representative building wall. Moreover, the registered curves are of great interest in order to validate numerical codes.

The study shows that the response time of the uncoated wall is short as well as for temperature as for humidity. Depending on initial and final setpoints, various phenomena are highlighted:

- under isothermal conditions with vapour pressure gradient, an homogeneous vapour diffusion is shown,

- under constant vapour pressure with a decrease of ambient temperature, huge variations of vapour pressure are observed within the wall. This underlines sorption-desorption and/or evaporationcondensation phenomena. 
The investigation, performed under moderate climate, could carried on under severe conditions too. It could be interesting to study the response to low temperature to analyse the possibility of occurrence of frost in the wall.

The results in the line of frame show that the frame doesn't induce disturbances in the hygrothermal behaviour of the wall. Besides, the frame is not a thermal bridge as the thermal conductivity of wood is similar to the one of hemp concrete.

The study on coated wall, under vapour pressure gradient and for isothermal conditions, shows that the coating reduces vapour pressure through the wall and delays the vapour diffusion due to an additional moisture resistance. However, it does not stop the sorption-desorption and/or evaporation-condensation phenomena in hemp concrete.

Finally, such hygric phenomena directly impact the heat balance equation in correlation with latent heat of phase-change or sorption heat. It is thus necessary to consider the contribution of hygric behaviour in the whole energetic performance of these materials. In order to highlight this contribution, it is necessary to develop new experimental benches.

\section{Acknowledgements}

This study was performed with the financial support of Brittany council within the PRIR Ecomatx project.

\section{References}


[1] S. Pretot, F. Collet, C. Garnier, Life Cycle Assessment of a hemp concrete wall : impact of thickness and coating, Building and Environment 72C, pp. 223-231, 2014. DOI information:

10.1016/j.buildenv.2013.11.010.

[2] L. Arnaud, Mechanical and thermal properties of hemp mortars and wools: experimental and theoretical approaches, in: 3 Symp Int of biore-source hemp, 2000.

[3] S. Elfordy, F. Lucas, F. Tancret, Y. Scudeller, L. Goudet, Mechanical and thermal 415 properties of lime and hemp concrete ("hempcrete") manufactured by a projection process. Construction and Building Material, 22(10), pp 2116-23, 2008.

[4] S. Benfratello, C. Capitano, G. Peri, G. Rizzo, G. Scaccianoce, G. Sorrentino, Thermal and structural properties of a hemp-lime bio-composite, Construction and Building Materials, 48, pp 745-754, 2013.

[5] T. Pierre, T. Colinart, P. Glouannec, Measurment of thermal properties of biosourced building materials, Int J Thermophysics, DOI 10.1007/s10765-013-1477-0, 2013.

[6] E. Sassoni, S. Manzi, A. Motori, M. Montecchi, M. Canti, Novel sustainable hemp-based composites for application in building industry: physical, thermal and mechanical characterization, Energy and Buildings, 77, pp 219-226, 2014.

[7] R. Walker, S. Pavía, Moisture transfer and thermal properties of hemp-lime concretes, Construction and Building Materials, 64, pp 270-276, 2014.

[8] F. Collet, S. Pretot, Thermal conductivity of hemp concretes: variation with formulation, density and water content, Construction and Building Materials , 65, pp 612-619, 2014, DOI information:

10.1016/j.conbuildmat.2014.05.039

[9] Bio-aggregate-based Building Materials, Applications to Hemp Concrete, edited by Amziane S. and Arnaud L., ISTE Ltd and John Wiley \& Sons, Inc, 2013. 
[10] P. de Bruijn, P. Johansson, Moisture fixation and thermal properties of lime-hemp concrete, Construction and Building Materials, 47, pp 1235-1242, 2013.

[11] F. Collet, Caractérisation hydrique et thermique de matériaux de génie civil à faibles impacts environnementaux, phD Thesis, INSA de Rennes, décembre 2004.

[12] V. Cerezo, Propriétés mécanique, thermique et acoustique d'un matériau à base de particules végétales : approche expérimentale et modélisation théorique, phD Thesis, ENTPE, INSA de Lyon, juin 2005 .

[13] F. Collet, M. Bart, L. Serres, J. Miriel, Porous structure and water vapour sorption of hemp-based materials, Construction and Building Material, 2008;22:1271-80.

[14] F. Collet, J. Chamoin, S. Prétot, C. Lanos, Comparison of the hygric behaviour of three hemp concretes, Energy and Buildings, 62, pp 294-303, 2013.

[15] A. Evrard, Transient hygrothermal behavior of Lime-Hemp materials, Ph.D. Thesis, Université catholique de Louvain, 2008.

[16] Réglementation Thermique 2005, Règles Th-U - Fascicule 2.

[17] A. Evrard, Sorption behaviour of Lime-hemp concrete and its relation to indoor comfort and energy demand. In: 23rd Conference on passive and low energy architecture, Geneva, Switzerland; 6-8 September, 2006.

[18] A.D. Tran Le, Etude des transferts hygrothermiques dans le béton de chanvre et leur application au bâtiment. PhD thesis, Université de Reims Champagne- Ardenne; November 2010 (in French).

[19] F. Collet, S. Pretot, Experimental investigation of moisture buffering capacity of sprayed hemp concrete., Construction and Building Materials, 36, pp 58-65, 2012. 
[20] S. Dubois; A. Evrard, F. Lebeau, Hygrothermal modelling of Lime-Hemp concrete used as building material and indoor climate buffering characterization. International Conference of Agricultural engineering, Valence, Espagne, 2012 july 8th to 12th, 2012.

[21] S. Dubois, A. Evrard, F. Lebeau, «Modeling the hygro-thermal behavior of biobased construction materials»; Journal of Building Physics; 2013.

[22] M. Barclay, N. Holcroft, A.D. Shea, Methods to determine whole building hygrothermal performance of hemp-lime buildings, Building and Environment, 80, pp 204-212, 2014.

[23] C. Rode, Moisture Buffering of Building Materials, Report BYG·DTU R-126, 2005, ISSN 16012917, ISBN 87-7877-195.

[24] A.D. Tran Le, C. Maalouf, T.H. Mai, E. Wurtz, F. Collet, Transient hygrothermal behavior of a hemp concrete building envelope, Energy and buildings, 42, 1797-1806, 2010.

[25] A. Evrard and A. De Herde, Hygrothermal per-formance of lime-hemp wall assemblies, Journal of building physics, 34, 15-25, 2010.

[26] A. Shea, M. Lawrence, P. Walker, Hygrothermal performance of an experimental hemp-lime building, Construction and Building Materials, 36, pp 270-275, 2012.

[27] J. Mlakar , J.Strancar, Temperature and humidity profiles in passive-house building blocks, Building and Environment, 60, pp 185-193, 2013.

[28] M. Woloszyn, T. Kalamees, M.O. Abadie, M. Steeman, A. Sasic Kalagasidis, The effect of combining a relative-humidity-sensitive ventilation system with the moisture- buffering capacity of materials on indoor climate and energy efficiency of buildings, Building and Environment, 44, pp 515524, 2009. 
[29] C. Maalouf, A.D. Tran Le, S.B. Umurigirwaa, M. Lachia, O. Douzane, Study of hygrothermal behaviour of a hemp concrete buildingenvelope under summer conditions in France, Energy and Building, 77, pp 48-57, 2014.

[30] Y. Ait Oumeziane, Evaluation of the hygrothermal performance of a wall by numerical simulation: application to hemp concrete walls [In French]. PhD thesis, Université Européenne de Bretagne - Institut National des Sciences Appliquées de Rennes; 2013.

[31] F. Collet, S. Pretot, Effect of coating on moisture buffering of hemp concrete, 2nd International conference on building energy and environment, Boulder, Colorado, august 1-4, 2012. 


\section{ACCEPTED MANUSCRIPT}

- We report the construction of a hemp concrete test-wall as separating wall of bi-climatic rooms.

- The hygrothermal behaviour of the wall is investigated under several hygrothermal stresses.

- Vapour diffusion, evaporation-condensation, sorption-desorption phenomena are shown.

- It is shown that the frame doesn't disturb the hygrothermal behaviour of the wall.

- It is also shown that the coating reduces and delays vapour diffusion. 